Available online at GSC Online Press Directory

GSC Biological and Pharmaceutical Sciences

e-ISSN: 2581-3250, CODEN (USA): GBPSC2

Journal homepage: https://www.gsconlinepress.com/journals/gscbps

(RESEARCH ARTICLE)

\title{
Characterization and role of pendimethalin catabolizing bacteria isolated from agricultural soil in Bauchi, Bauchi state
}

\author{
Wali Mu'azzam Mu'azu ${ }^{1}$, ${ }^{*}$, Ibrahim Yusuf Okpanachi ${ }^{2}$, Umar Ahmad Faruq ${ }^{1}$ and Tahir Fatimah ${ }^{1}$ \\ ${ }^{1}$ Department of Biological Science, Abubakar Tafawa Balewa University, Bauchi, Nigeria. \\ 2 Department of Botany, University of Lagos, Nigeria
}

Publication history: Received on 30 October 2018; revised on 21 November 2018; accepted on 26 November 2018

Article DOI: https://doi.org/10.30574/gscbps.2018.5.3.0126

\begin{abstract}
The characterization and role of pendimethalin catabolizing bacteria isolated in three agricultural soils in Bauchi state. Analyses of physico-chemical parameters were carried out to further understand the soil environmental conditions of the sampling sites. Aerobic heterotrophic counts on the sampling sites for six (6) weeks were conducted and revealed increase of bacterial counts across the weeks; with the first week having low bacterial count of $104.333\left(\times 10^{5} \mathrm{cfu} / \mathrm{g}\right)$ while week six (6) had the highest bacterial counts of $202.5\left(\times 10^{5} \mathrm{cfu} / \mathrm{g}\right)$. Among the sampling sites: B1 and B2 had the lowest bacterial count compared to B3. This is as a result of the effects of herbicides accumulation in the soil. Bacterial abundance across the sampling sites showed high percentage of occurrence of Bacillus sp., Pseudomonas sp., Morganella sp.at (14.25\%) each; when compared to Streptococcus sp. and Proteus sp.at (4.29\%). The isolation of pendimethalin utilizing bacteria was conducted by enrichment cycle using mineral salt media containing pendimethalin (mg/ml) as a sole carbon source. Utilization patterns of pendimethalin degrading potentials of bacterial strains was determined via growth, utilization patterns and higher performance liquid chromatography analysis. Growth and utilization was monitored using spectrophotometer at $600 \mathrm{~nm}$. Bacillus sp. and bacterial consortia showed high level of wavelengths at 0.424 and 0.481 respectively. High performance liquid chromatography analysis was conducted for 72 hours based on the peak reduction of standard pendimethalin and observed was a decrease in the area of the peak. Bacillus $s p$., Pseudomonas $s p$. revealed the highest rate of pendimethalin metabolism after 72 hours. Based on this research, indigenous microorganisms can be used for decontamination of agricultural soil. The Nigerian government and farmers at large should be careful on the type herbicides used for agricultural practices. For it affects soil microorganisms and crops.
\end{abstract}

Keywords: Pendimethalin; Agricultural soil; Catabolizing bacteria; Crops

\section{Introduction}

Pendimethalin (N-(1-ethylpropyl)-2, 6-dinitro-3, 4-xylidine) has the empirical formula $\mathrm{C}_{13} \mathrm{H}_{19} \mathrm{~N}_{3} \mathrm{O}_{4}$, it is an active ingredient of a selective pre-emergence herbicide, a dinitroaniline group which is used extensively for weed control in cotton, rice, maize and tobacco [1].

Pendimethalin acts by inhibiting the steps in plant cell division responsible for chromosome separation and cell wall formation. It is used before crop emergence or planting [2]. The inhibition of root and shoot growth results in stunting of aerial plant portions [3].

Pendimethalin is also highly toxic to fish and aquatic invertebrates. However, its use may adversely affect endangered species of terrestrial and semi aquatic plants and invertebrates including molluscs, fishes and birds. Care should be

\footnotetext{
${ }^{*}$ Corresponding author

E-mail address: muazzamwl7@gmail.com
} 
taken to minimize excessive pendimethalin applications to the soil in order to minimize possible injury to sensitive rotation crops. Microorganisms can use a variety of xenobiotic compounds including herbicides for their growth, mineralize and detoxify them [3].

The microbial degradation of many modern herbicides requires a group of consortium of microbes [3]. There are some reports on the degradation of pendimethalin by microorganisms comprising Azotobacter chroococcum, $A$. vinelandii and Bacillus circulans [4], [5]. The success of bioremediation depends not only on the high degradation ability but also on the stability of active microorganisms under varied conditions, such as changes in $\mathrm{pH}$ and temperature [6]. Therefore, it is necessary to investigate the effects of various environmental factors on the growth ability of the tested microorganisms [7]. Degradation of these pesticide by indigenous microbiota in soil can efficiently remove pesticide from the environment, especially Pendimethalin and the likes of it used in Agriculture [7].

\section{Material and methods}

\subsection{Sampling sites}

Soil samples were collected from three (3) different cultivated sites in Bauchi metropolis, Bauchi local government area. Two (2) sites with the history of herbicide, pendimethalin application and both are actively involved in Agricultural activities, designated as $\mathrm{B}_{1}$ and $\mathrm{B}_{2}$. The third site, a plot not actively involved in agricultural activity and no history of herbicide, pendimethalin application, designated as $B_{3}$, located at rafin zurfi, rafin makaranta and sabon kaura respectively.

\subsection{Soil sampling and collection}

Soil samples were collected at a depth of $10 \mathrm{~cm}$ using soil auger. A stratified random sampling was adopted, where, sample site(s) are divided into equal sub-plots. From each sub-plot, a simple random sampling was done and mixed thoroughly to make a composite sample, approximately $100 \mathrm{~g}$ each.

Soil samples were collected on weekly basis for six (6) weeks [8]. Samples were placed in a sterilized polyethene container and labelled as $\mathrm{B}_{1}, \mathrm{~B}_{2}, \mathrm{~B}_{3}$. Soil collected are transported to the Post graduate laboratory of Abubakar Tafawa Balewa University, Bauchi. For analysis [8].

\subsection{Sources of analytical pendimethalin}

Analytical pendimethalin used for this study was purchased from sigma-aldrich pestanal standard 36191, United Kingdom. All other chemicals used were of analytical reagent grade.

\subsection{Determination of soil physico-chemical parameters}

\subsubsection{Soil pH (soil to water) method}

This was determined using the 'soil to water' method where $20 \mathrm{~g}$ of air dried soil was placed in a $50 \mathrm{ml}$ beaker and 20 $\mathrm{ml}$ of distilled water was added and the mixture was placed on mechanical shaker for 30 min. Already standardized electrode of pH meter was placed into partly settled suspension and measurement taken as described by [8].

\subsubsection{Soil temperature}

Soil temperature was measured in situ; using mercury -in- glass thermometer, using method described by [8]. Thermometer was dipped in various points of top soil, $10 \mathrm{~cm}$ depth, at the sampling site and average reading was taken.

\subsubsection{Soil organic carbon}

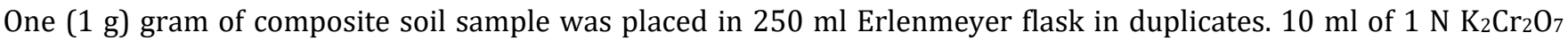
solution was added to the flask and swirled gently to disperse the soil. $20 \mathrm{ml}$ of Conc. $\mathrm{H}_{2} \mathrm{So} 4$ was added in stream into the suspension. The mixture was allowed to stand for $30 \mathrm{~min}$ in fume cupboard and distilled water was added, followed by four (4) drops of Ferroin indicator and titrated against $0.5 \mathrm{~N}$ ferrous sulphate solution. The amount of organic carbon was calculated as described by [11]. Until the colour changes from black to brown.

$$
\% \text { Orgnic carbon }=\frac{\left(1-\frac{\mathrm{T}}{\mathrm{S}}\right) \times 100 \times \mathrm{N} \times 0.003 \times 10 \mathrm{~mL}}{O D W}
$$


Where:

$\mathrm{N}=$ Normality of $\mathrm{K} 2 \mathrm{Cr} 2 \mathrm{O} 7$ solution

$\mathrm{T}=$ Volume of FeSO4 used in sample titration $(\mathrm{mL})$

$\mathrm{S}=$ Volume of FeSO4 used in blank titration $(\mathrm{mL})$

ODW= Oven-dry sample weight (g)

\subsubsection{Soil particle size}

$50 \mathrm{~g}$ of $2 \mathrm{~mm}$ sieved soil sample was placed in a clean plastic beaker. The $50 \mathrm{ml}$ of $5 \%$ Sodium hexametaphosphate (Calgon) was added and stirred for $24 \mathrm{hrs}$. The mixture was transferred into $1000 \mathrm{ml}$ measuring cylinder and a plunger was used to mix the suspension. Hydrometer was used to take the first reading as $\mathrm{H}_{1}$ and temperature as $\mathrm{T}_{1}$ respectively. The set-up was allowed to stand for $24 \mathrm{hrs}$ and second hydrometer $\left(\mathrm{H}_{2}\right)$ and temperature $\left(\mathrm{T}_{2}\right)$ reading was recorded. Results of particle size (\%) were calculated as follows [9], [10].

Sand $=100.0-\left(\mathrm{H}_{1}+0.2\left(\mathrm{~T}_{1}-68\right)-2.0\right)^{2}$

Clay $\left.=\left(\mathrm{H}_{2}+0.2\right)\left(\mathrm{T}_{2}-68\right)-2.0\right)^{2}$

Silt $=100-($ Sand + Clay $)$

\subsubsection{Soil moisture}

Moisture content was determined by constant weight methods, as described by [8]. The initial weight of composite soil sample was obtained and dried in the oven at $105^{\circ} \mathrm{C}$ until constant weight was obtained. The weight difference was recorded and percentage calculated as;

$$
\% \text { Moisture }=\frac{\text { Initial weight }- \text { Constant weight }}{\text { Initial weight }} \times 100
$$

\subsection{Microbial analysis of aerobic heterotrophic bacterial counts}

One gram ( $1 \mathrm{~g}$ ) of soil sample was weighed using weighing balance and placed into a sterile Eppendorf tube containing $10 \mathrm{ml}$ freshly prepared trypticase soy broth (TSB) and distilled water respectively. The mixture was allowed to stay for $6 \mathrm{hrs}$ and decimal dilution of the thoroughly mixed was made to obtain $10^{1}$ to $10^{7}$ concentration gradients. Aliquots of $0.1 \mathrm{ml}$ of $10^{5}$ dilutions from Eppendorf tube and test tube was plated in triplicates plates of trypticase soy agar (TSA) and Nutrient agar respectively. Using pour plate method. Plates were inoculated at room temperature. Observe colonies are counted using colony counter and expressed by [8].

$$
T B C=\frac{N}{V} \times R
$$

$\mathrm{N}$ = Number of colour; $\mathrm{V}=$ Volume of dilution; $\mathrm{R}$ = Dilutions factor

\subsection{Isolation of pendimethalin utilizing bacteria by enrichment technique using pendimethalin as carbon source}

A modified [11] was used as adopted by [8]. $1 \mathrm{~g}$ of Soil sample was added to $100 \mathrm{ml}$ of MSM containing mg/ml of pendimethalin as a sole carbon source, then incubate at room temperature for 14 days using incubator shaker. After the period of two (2) weeks, $0.1 \mathrm{ml}$ was plated on MSM agar containing $\mathrm{mg} / \mathrm{ml}$ of pendimethalin. MSM agar served as control. All sets of plates were inoculated in triplicates. $3 \mathrm{ml}$ of fulcin (griseofulvin) was used in $100 \mathrm{ml}$ MSM to selectively knock-off fungal contamination in each set of media preparation.

The plates were inoculated at $25^{\circ} \mathrm{C}$ for observations. The strain exhibiting best mineralization ability was selected for further studies. The same set of enrichment and isolation procedure was carried out for each of the different composite soil samples. After the enrichment cycle, positive strain was plated on Luria Bertani (LB) and further screen for pendimethalin-degradation [11]. 


\subsection{Characterization of pendimethalin-degrading bacteria}

Growth and biochemical characteristics of pendimethalin-degrading bacterial strain was based on their growth on LB media. Their gram reaction and colonial shapes, colour. Consistency and biochemical tests such as catalase, urease, methyl red, voges proskauer, kovac's oxidase. The result obtained was compared with those of bergey's manual for determinative bacteriology [12].

\subsubsection{Citrate utilization test}

This is based on the ability of an organism to use citrate as its only source of carbon. Simmon citrate agar was used to prepare slopes in bijou bottles and stored at $28^{\circ} \mathrm{C}$. Using a sterile wire loop, the slope was first streaked with a saline suspension of the test organism and the butt was stabbed. The medium was then incubated at $35^{\circ} \mathrm{c}$ for $48 \mathrm{~h}$. The test was used to differentiate between klebsiella sp., whereas a yellow orange colour is a negative citrate test indicating the presence of E. coli. [13].

\subsubsection{Indole test}

In detecting indole, tryptone water was used, the test organism was inoculated in a bijou bottle containing $3 \mathrm{ml}$ of sterile tryptone water, and was incubated at $35-37^{\circ} \mathrm{C}$ for up to $48 \mathrm{~h}$. Kovac's reagent of about $0.5 \mathrm{ml}$ was added and the mixture shaken gently. It was examined for a red colour in the surface layer within ten minutes. A red surface is positive for indole while no red surface shows negative indole test. Most strain of E. coli, Proteus sp.., Morganella morganii and Providencial sp. are indole positive.

\subsubsection{Urease test}

Christensen's urea broth was used. The test organism was heavily inoculated in a bijou bottle containing $3 \mathrm{ml}$ sterile Christensen's modified broth. It was then incubated at $35-37{ }^{\circ} \mathrm{C}$ for $3-12 \mathrm{~h}$. A pink colour is positive for urease while absence of pink colour is negative for urease test. This test helps in differentiating enterobacteriaceae. For example, Proteus strains are strong urease producers.

\subsubsection{Methyl Red (MR test)}

The organisms were inoculated in a test tube containing peptone water for 24 hours, 3 drops of MR reagent were added to the mixture. Formation of a ring red colour indicates positive result. This test was used to determine the ability of the organism to produce and maintain stable acid end products from glucose fermentation and to overcome the buffering capacity of the system.

\subsubsection{Voges Proskauer (Vg) test}

The test was used to determine the ability of the organisms to produce neutral end product acetyl methyl carbinol [8] from glucose fermentation. It was carried out by incubating the test organism for 24 hours on peptone water broth. 2 drops of $\mathrm{Vg}$ reagent were made on the overnight culture. Indication of pinkish red at the surface of the medium signifies positive result, while yellowish colour at surface of the media shows negative result.

\subsection{Pendimethalin utilization patterns of the different isolates}

\subsubsection{Inoculum preparation and standardization}

Inocula used for the study were prepared by inoculating isolates into Nutrient broth and incubated at $30{ }^{\circ} \mathrm{C}$ for $24 \mathrm{~h}$; using sterile normal saline, the cells from the culture were suspended to a 0.5 McFarland nephelometer standard (Optical density of 0.17 at $600 \mathrm{~nm}$ ) [8].

\subsubsection{Growth and utilization patterns of the isolates}

The growth characteristics of strains obtained from various soil samples were evaluated using MSM containing mg/ml of pendimethalin. The inoculum containing pendimethalin degrading isolates was placed in a vial containing $1 \mathrm{ml}$ of MSM mg/ml pendimethalin. The growth was determined by monitoring the Optical density (OD $600 \mathrm{~nm}$ ) of growth medium, at interval of $24 \mathrm{~h}$ to $144 \mathrm{~h}$ incubation period, using spectrophotometer. All experiment was carried out in triplicates, and the average (mean) was used to plot graph of cell growth versus time (h) [8]. Vials with no inoculation was used as control in all sets of the experiments [5]. 


\subsubsection{High performance liquid chromatography (HPLC) analysis of pendimethalin utilization}

High performance liquid chromatography was carried out with Agilent 1200 series. The HPLC separation was carried out using an RP C18 column (100 mm x $2.1 \mathrm{~mm}$ x $5 \mu \mathrm{m})$. The mobile phase was composed of methanol: water (20:80 $\mathrm{u} / \mathrm{v} 0.15 \%$ formic acid). The mobile phase flow rate was $0.9 \mathrm{~mL}^{-1}$ and column temperature was maintained at $35^{\circ} \mathrm{c}$. Samples from the growth media were collected at regular interval from $24 \mathrm{~h}, 48 \mathrm{~h}$, and $72 \mathrm{~h}$. The filtered mixture was collected by centrifugation and ethyl acetate was used to extract the end product of pendimethalin degradation from the culture supernatant. The methanol was us utilized to dissolve the residue from extraction [5].

\section{Results and discussion}

Table 1 Physico-chemical properties of soil collected from the three study sites

\begin{tabular}{lccc}
\hline Parameters & \multicolumn{3}{c}{ Sample sites } \\
& B1 & B2 & B3 \\
\hline Pendimethalin application history & + & + & - \\
Soil type & - & - & - \\
Temperature $\left({ }^{\circ} \mathrm{C}\right)$ & 23.5 & 23.7 & 24 \\
pH & 5.4 & 5.2 & 7.1 \\
Soil moisture (\%) & 12 & 13 & 10 \\
Organic carbon (\%) & 19.7 & 20.8 & 23.1 \\
Particle size (\%) & & & \\
Sand & 72 & 69 & 63.5 \\
Silt & 5 & 5 & 8.1 \\
Clay & 6 & 6 & 16.3 \\
\hline
\end{tabular}

B1: Pendimethalin contaminated soil Rafin Zurfi, B2: Pendimethalin contaminated soil Rafin Makaranta, B3: Non-pendimethalin contaminated soil Sabon Kaura

The highest mean temperature value of $24{ }^{\circ} \mathrm{C}$ was recorded at $\mathrm{B} 3$, while the least was recorded at sample sites $\mathrm{B}_{1}(23.5$ ${ }^{\circ} \mathrm{C}$ ). The highest average $\mathrm{pH}$ value was recorded at $\mathrm{B}_{1}$ and $\mathrm{B}_{2}$ (5.4 and 5.2 respectively). While the pH value of 7.1 were recorded at sample sites $B_{3}$. Moisture content of $13 \%, 12 \%$ and $10 \%$ were gotten from sample sites $B_{1}, B_{2}$ and $B_{3}$ respectively. The percentage organic carbon showed that, $\mathrm{B} 3$ with $23.1{ }^{\circ} \mathrm{C}$ which is the highest, $\mathrm{B}_{2} 20.8 \%$, and the least was observed at B1. Particle size percentage showed a relatively higher percentage (\%) of sand and moderate percentage of silt and clay, which tells about the type of soil present. $\mathrm{B}_{1}$ has the highest percentage of sand (72.1\%) and low percentage of Silt and clay ( 5 and 6). $B_{2}$ has the least percentage of 63.5 sand, and higher percentage of silt and clay (8.1 and 16.3 respectively) as compared to $\mathrm{B}_{1}$ and $\mathrm{B}_{3}$.

Of the three sample sites analyzed, the average soil temperature ranged between $23-24{ }^{\circ} \mathrm{C}$ were observed. Many authors have established links between soil temperature and persistence of herbicides in soil. However, this range of temperature varies with the report of agro metrological center ATBU, 2016, which shows the average soil temperature of $25-30{ }^{\circ} \mathrm{C}$ from January to October, 2016. A temperature changes affect not only the physiological reactions of microbial cells but also the characteristics of soil environment [14]. However, an increase in temperature accelerates the degradation of soil-acting herbicides, while decrease in temperature affect the degradation rates which leads to persistence of herbicides in soil.

Table 2 Mean aerobic heterotrophic bacterial counts of three sample site

\begin{tabular}{lccccccc}
\hline \multirow{2}{*}{ Sample sites } & \multicolumn{7}{c}{ Microbial counts $\mathbf{( \times \mathbf { 1 0 }} \mathbf{\mathbf { C f u }} \mathbf{\text { g) }} \mathbf{0}$ of soil samples at different weeks } \\
& $\mathbf{1}$ & $\mathbf{2}$ & $\mathbf{3}$ & $\mathbf{4}$ & $\mathbf{5}$ & $\mathbf{6}$ & Total \\
\hline B1 & 58 & 88 & 84 & 114 & 192 & 108 & 107.33 \\
B2 & 120 & 68 & 115 & 177 & 118 & NS & 119.6 \\
B3 & 135 & 189 & 184 & 202 & 239 & 297 & 207.66 \\
Total & 104.33 & 115 & 127.66 & 164.33 & 183 & 202.5 & 149.47 \\
\hline
\end{tabular}

B1: Pendimethalin contaminated soil Rafin Zurfi, B2: Pendimethalin contaminated soil Rafin Makaranta, B3: Non-pendimethalin contaminated soil Sabon Kaura. Within Sample Sites $(\mathrm{P}>0.05)=0.06$, Within Weeks $(\mathrm{P}>0.05)=0.813$ 
The observed trends in microbial populations were similar to observation made by [15] discovered that, higher concentrations of herbicides resulted in much lower microbial counts when compared to soils without contamination of herbicides.

Experiments have shown that microbes use herbicides as a source of carbon [15]. This may consequently explain the increase in bacterial populations in sample sites $\mathrm{B}_{3}$ as compared with sites $\mathrm{B}_{1}$ and $\mathrm{B}_{2}$. The bacterial populations for all soil sample increases from week 1 with the counts of $104.33 \times 10^{5} \mathrm{cfu} / \mathrm{g}$. The second week had the second least with the population of $115 \times 10^{5} \mathrm{cfu} / \mathrm{g}$. From the third to sixth weeks showed a little variation in bacterial counts, with sixth week having the highest bacterial counts of $202.5 \times 10^{5} \mathrm{cfu} / \mathrm{g}$. Analysis of variance at $\mathrm{p}=0.05$ showed significant difference among the weeks.

Table 3 Distribution of bacterial isolated from three sample sites

\begin{tabular}{lll}
\hline Isolates & Frequency of occurrence & Percentage (\%) \\
\hline Pseudomonas $s p$. & 9 & 14.29 \\
Acinetobacter $s p$. & 6 & 9.52 \\
Enterococcus $s p$. & 9 & 14.29 \\
Bacillus sp. & 9 & 14.29 \\
Morganella sp. & 9 & 14.29 \\
Enterobacter sp. & 6 & 9.52 \\
Streptococcus sp. & 3 & 4.76 \\
Proteus sp. & 3 & 4.76 \\
Lactobacter sp. & 9 & 14.29 \\
Total & 63 & 100.00 \\
\hline
\end{tabular}

B1: Pendimethalin contaminated soil in Rafin Zurfi, B2: Pendimethalin contaminated soil in Rafin Makaranta, B3: Non-pendimethalin contaminated soil in Sabon Kaura

Table 3 shows the distribution of bacteria isolated from sample sites B1, B2, and B3 with their frequency and percentage of occurrence. Nine (9) bacterial species with the total frequency of 63, were isolated. Out of which Streptococcus sp. and Proteus sp. has the least percentage of occurrence of $4.79 \%$, followed by Acinetobacter sp. and Enterobacter sp. with $9.52 \%$ each. The highest of occurrences of $14.29 \%$ were recorded on Pseudomonas sp., Enterococcus sp., Lactobacillus sp., and Bacillus sp.

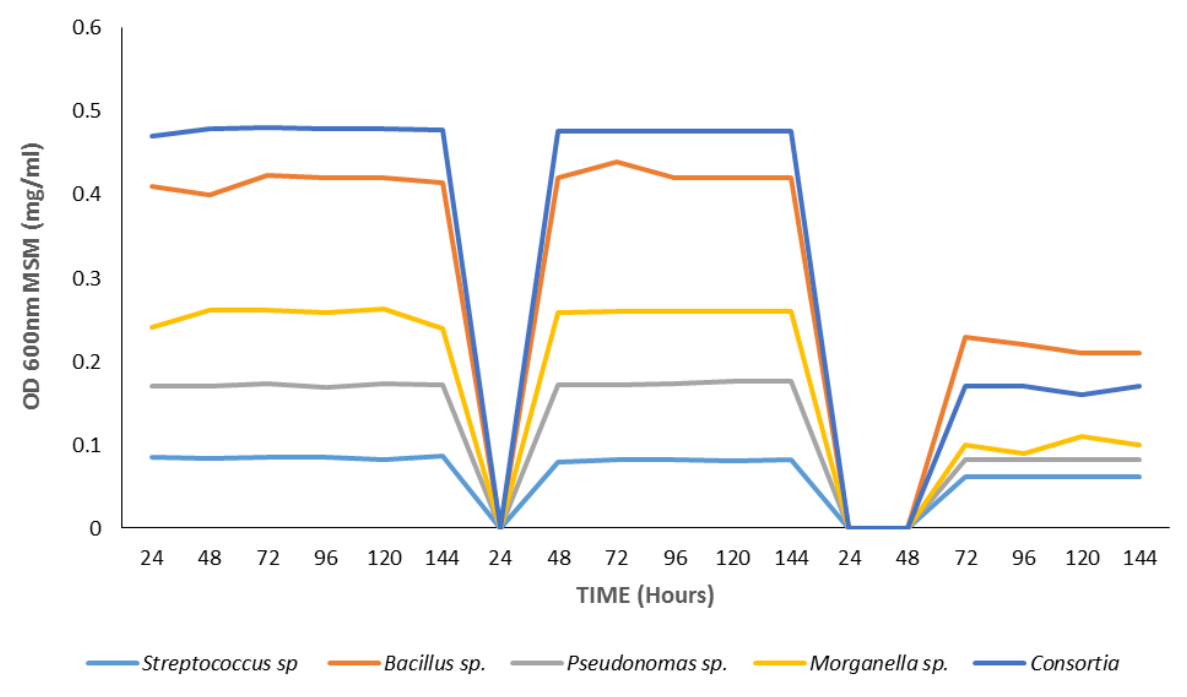

Figure 1 Growth and pendimethalin utilization pattern of the isolates

Growth and pendimethalin utilization pattern of bacterial strain isolated from the sample sites were conducted using Spectrophotometer at a wave length of $600 \mathrm{~nm}$ (OD). Cell growth gave a range of 0.084 to 0.481 . High growth rate was observed on Bacillus sp. (0.424) in both the two contaminated soils (B1 and B2) as shown in Figure 1, with the least growth in Streptococcus sp. The consortia showed a uniform growth pattern of 0.421 . 


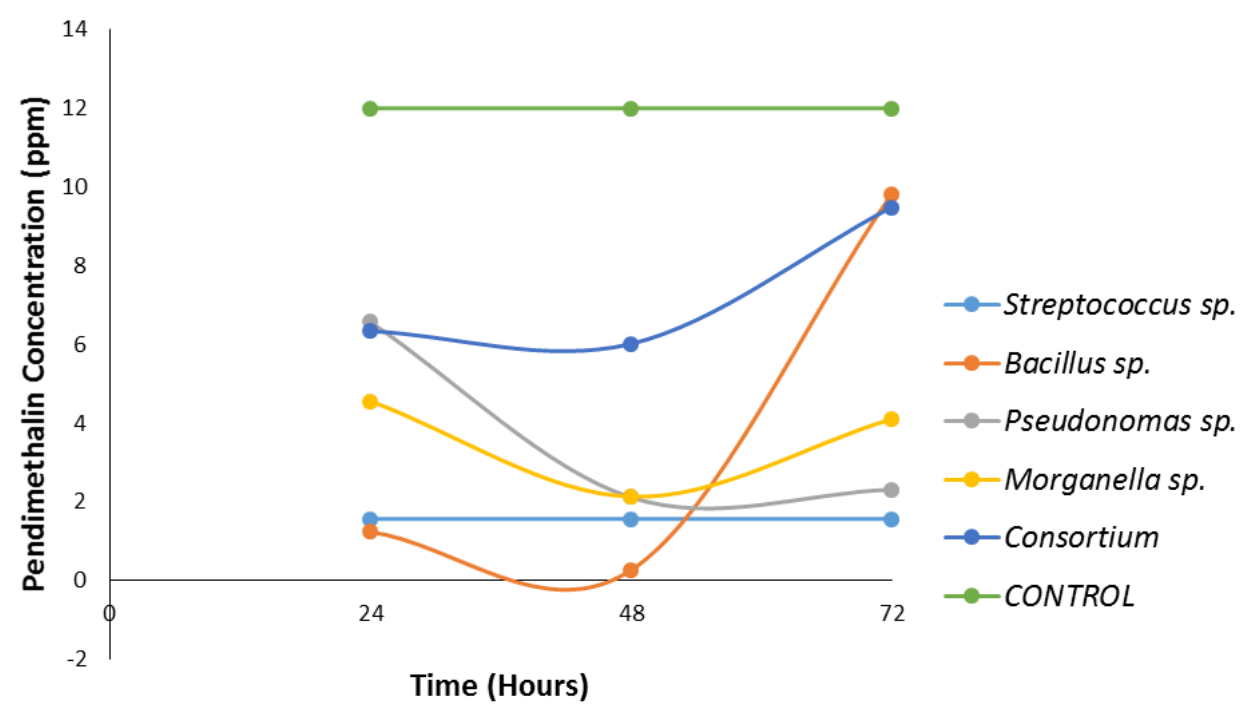

Figure 2 High performance liquid chromatography analysis of pendimethalin utilization

Analysis of pendimethalin utilization by pendimethalin-degrading bacterial isolates in MSM containing pendimethalin (in $\mathrm{mg} / \mathrm{ml}$ ) was determine based on the herbicides reduction on the standard curve. The extent of metabolism was evident from the reduction of peak of standard pendimethalin curve as shown in Figure 2. HPLC analysis was conducted on the degrading bacterial strain for 72 h. (i.e. 24 h, $48 \mathrm{~h}$ and $72 \mathrm{~h}$ ). Four bacterial strain were used, out of which Bacillus $s p$. and bacterial consortia showed a significant higher rate of pendimethalin metabolism of $8.234 \mathrm{ppm}$ and $8.412 \mathrm{ppm}$ accordingly, after $72 \mathrm{~h}$. While, Streptococcus sp. shows a uniform utilization rate of $1.5 \mathrm{ppm}$.

\section{Conclusion}

From this study, it was discovered that Agricultural soils with history of pendimethalin application has a low pH and lower bacterial counts as compared to agricultural soils without the history of pendimethalin application or other chemicals. This is due to accumulation or carryover effects of the herbicides used in soils that leads to presence of heavy metals such as arsenic, aluminum which affects the microbial population that can decompose the accumulated herbicides. It was further revealed that; bacterial population increases as the herbicides stays longer in the soil. This study highlighted the diversity of bacteria in the study sampling sites and showed a total number of nine (9) bacterial isolates were identified, ranging from; Streptococcus sp. and Proteus sp. appeared to be not common in the sampling sites, while, Bacillus sp., Streptococcus sp. Enterococcus sp., Morganella sp. and Bacillus sp. appeared to be common. This may be due to their ability to adapt to their environmental changes. Moreover, the study revealed that, bacterial strains isolated from three sampling sites were able to grow and utilized pendimethalin as a sole-carbon source which makes them a tool for bioremediation that could be used in making the environment friendly. Bacillus sp. and bacterial consortium showed an appreciable growth pattern of OD 0.424 and OD 0.481 respectively. Analysis of pendimethalin utilization by High Performance Liquid Chromatography revealed pendimethalin utilization are best achieved by Bacillus sp., Pseudomonas sp. and bacterial consortium. This also proves the use of Bacillus sp., Pseudomonas sp. and bacterial consortium for clearing the environment. Bacillus sp. and bacterial consortia show a promising result and growth pattern of OD 0.424 and 0.481 respectively. Analysis of pendimethalin utilization by HPLC revealed higher reduction of pendimethalin by Bacillus sp. and Pseudomonas sp.., this proves the capability of Bacillus sp., Pseudomonas $s p$. and bacterial consortium indigenous to the sampling sites as a good agent of bioremediation of herbicides contaminated sites. Due to excessive use of herbicides, ecosystems are under threat of its pollution. Microbes are the main vehicle for remediation of herbicides, and new discoveries, such as novel biodegradation pathways, multispecies interactions and community-level responses to herbicides addition, are helping us to understand, predict and monitor the fate of herbicides. With the recent release of new metagenomic information from herbicides-associated environments determining the microbial players offers the promise of new discovery. Genomic, transcriptomic and mutant studies conducted with defined co-cultures are yielding new information about how microbes interact and benefit energetically via different mechanisms of interspecies electron transfer. Despite this, there are many challenges, not least because of the heterogeneity of these ecosystems and the structure of herbicides. Microbial metabolism is a process of energy conversion, and it is governed by enzymatic mechanisms, where reaction intermediates play a vital role. Screening of organisms that degrade herbicides or produce enzymes or enzyme systems that degrade herbicides may prove as environmentally profitable in the present time. 


\section{Compliance with ethical standards}

\section{Acknowledgments}

We wish to thank laboratory staffs of Department of Biological Sciences for their contribution to the success of this research.

\section{Disclosure of conflict of interest}

There's no what so ever any conflict of interest we are giving the outfit full right to publication of this work.

\section{References}

[1] Smith AE, Aubin AJ and McIntosh TC. (1995). Field persistence studies with emulsifiable concentrate and granular formulations of the herbicide Pendimethalin in Saskatchewan. Journal of Agricultural and Food Chemistry, 43, 2988-2991.

[2] Appleby JR and Val Verde BE. (1988). Behavior of dinitroaniline herbicides in plants. Weed Technol. 3, $198-206$.

[3] Belal EB, Zidan NA, Mahmoud HA and Eissa FI. (2008). Bioremediation of pesticides - contaminated soils. Journal of Agricultural Research, 34, 588 - 608.

[4] Mandelbaum RT, Wackett LP and Allan DL. (1993). Rapid hydrolysis of Atrazine to hydroatrazine by soil Bacteria. Environmental science and technology, 1943-1944.

[5] Kole RA. (1994). Bacterial degradation of herbicide pendimethalin and activity evaluation of its metabolites. Bulletin of Environmental Contamination and Toxicology, 52, 779-786.

[6] Megadi BV, Preeti NT, Robertcryril S, Sikandar IM and Harichandra ZN. (2010). Biodegradation of Pendimethalin by Bacillus circulans. Indian Journal of Biotechnology, 9,173-177.

[7] Pattanasupong A, Nagase H, Inoue M, Hirata K, Tani K, Nasu M and Miyamoto K. (2004). Ability of microbial consortium to remove pesticide, carbendazim and 2, 4- dichlorophenoxyacetic acid. World Journal of Microbiology and Biotechnology, 20, 517-522.

[8] Umar AF, Tahir F, Larkin M, Oyawoye OM, Musa BL, Yerima MB and Agbo EB. (2012). In-situ biostimulatory effect of selected organic waste on bacterial atrazine biodegradation. Advances in Microbiology, 2(04), 587.

[9] Davidson AL. (1995). Soil Chemical Analysis, Prentice Hall, New York, 44-48.

[10] Black CA. (1965). Methods of Soil Analysis, American Society of Agronomy, 9(2), 12-15.

[11] Mandelbaum RT, Wackett LP and Allan DL. (1993). Rapid hydrolysis of Atrazine to hydroatrazine by soil Bacteria. Environmental science and technology, 1943-1944.

[12] John GH. (1984). Ordinary gram negative bacteria. In: Bergey's Manual of Systematic Bacteriology, Baltimore. USA: Williams and Wilkins Press.

[13] Cheesbrough M. (2000). District Laboratory Practice in Tropical Countries Part 2. UK: Cambridge University Press.

[14] Ayansina ADV. (2006). Effect of two commonly used herbicides on soil microflora at two different concentrations. African Journal of Biotechnology, 5(2), 129-132.

[15] Radosevich M, Traina SJ, Hao YL and Tuovinen OH. (1995). Degradation and mineralization of atrazine by a soil bacterial isolate. Applied and Environmental Microbiology, 61(1), 297-302.

\section{How to cite this article}

Wali MM, Okpanachi IY, Umar AF and Tahir F. (2018). Characterization and role of pendimethalin catabolizing bacteria isolated from agricultural soil in Bauchi, Bauchi state. GSC Biological and Pharmaceutical Sciences, 5(3), 12-19. 